\title{
A Preliminary Examination of the Supply and Demand Balance for Renewable Electricity
}

Technical Report NREL/TP-670-42266

October 2007

Blair Swezey, Jørn Aabakken, and Lori Bird 


\section{A Preliminary Examination of the Supply and Demand Balance for Renewable Electricity}

Blair Swezey, Jørn Aabakken, and Lori Bird
Technical Report NREL/TP-670-42266

October 2007

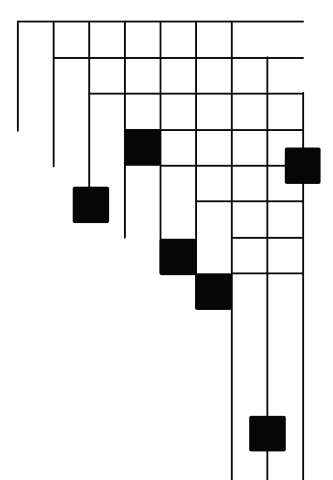

Prepared under Task No. WF6N.1015

National Renewable Energy Laboratory

1617 Cole Boulevard, Golden, Colorado 80401-3393

303-275-3000 - www.nrel.gov 


\section{NOTICE}

This report was prepared as an account of work sponsored by an agency of the United States government. Neither the United States government nor any agency thereof, nor any of their employees, makes any warranty, express or implied, or assumes any legal liability or responsibility for the accuracy, completeness, or usefulness of any information, apparatus, product, or process disclosed, or represents that its use would not infringe privately owned rights. Reference herein to any specific commercial product, process, or service by trade name, trademark, manufacturer, or otherwise does not necessarily constitute or imply its endorsement, recommendation, or favoring by the United States government or any agency thereof. The views and opinions of authors expressed herein do not necessarily state or reflect those of the United States government or any agency thereof.

Available electronically at http://www.osti.gov/bridge

Available for a processing fee to U.S. Department of Energy and its contractors, in paper, from:

U.S. Department of Energy

Office of Scientific and Technical Information

P.O. Box 62

Oak Ridge, TN 37831-0062

phone: 865.576 .8401

fax: 865.576 .5728

email: mailto:reports@adonis.osti.gov

Available for sale to the public, in paper, from:

U.S. Department of Commerce

National Technical Information Service

5285 Port Royal Road

Springfield, VA 22161

phone: 800.553 .6847

fax: 703.605.6900

email: orders@ntis.fedworld.gov

online ordering: http://www.ntis.gov/ordering.htm 


\section{Acknowledgments}

This work was funded by the U.S. Environmental Protection Agency's Green Power Partnership. The authors wish to thank Matt Clouse and Leslie Cordes for their support of this work. The authors also wish to thank the following individuals for providing thoughtful review comments: Doug Arent, David Hurlbut, and Laura Vimmerstedt of the National Renewable Energy Laboratory (NREL); Ed Holt of Ed Holt \& Associates Inc.; Lars Kvale of the Center for Resource Solutions; and Marcus Krembs of Sterling Planet. The authors also wish to thank Jennifer Josey of NREL for editorial support. 


\section{Introduction}

In recent years, the demand for renewable electricity has accelerated as a consequence of state and federal policies and the growth of voluntary green power purchase markets, along with the generally improving economics of renewable energy development. The National Renewable Energy Laboratory (NREL) ${ }^{1}$ estimates that U.S. green power sales totaled 8.5 million MWh in 2005 and approximately 12 million MWh in 2006. The 2006 figure represents a three-fold increase from just three years earlier. ${ }^{2}$ The U.S. Environmental Protection Agency's (EPA) Green Power Partnership has helped spur the phenomenal growth in commercial customer purchases, from less than 400,000 MWh in annual purchase commitments in 2001 to nearly 7 million MWh in 2006, an 18-fold increase in just five years. ${ }^{3}$

At the same time, 25 states plus the District of Columbia have enacted renewable portfolio standards (RPS) requirements ranging from $2 \%$ to $30 \%$ of total electricity supply, to be achieved over the next five to 15 years. However, U.S. non-hydro renewable electricity generation provided only about $2.3 \%$ of the total U.S. electricity supply in 2005 . $^{4}$ And global demand for renewable energy equipment is already leading to supply shortages for wind turbines and photovoltaic modules.

The EPA's Green Power Partnership encourages organizations to purchase green power as a way to reduce the environmental impacts associated with conventional electricity use, and has issued challenges to various electricity customer market segments, including colleges, universities, and Fortune 500 companies, to increase their green power purchases. However, the success of these initiatives depends on an adequate domestic supply of renewable electricity at a reasonable cost, and it is therefore important to assess whether the renewable energy industry can meet the increasing demand for renewable electricity.

This paper reports on a preliminary examination of the supply and demand balance for renewable electricity in the United States, with a focus on renewable energy projects that meet the generally accepted definition of "new" for voluntary market purposes, i.e., projects installed on or after January 1, 1997. After estimating current supply and demand, we present projections of the supply and demand balance out to 2010 and describe a number of key market uncertainties.

\footnotetext{
${ }^{1}$ Author Blair Swezey, formerly of NREL, is currently with Applied Materials, Santa Clara, Calif.

${ }^{2}$ Bird, L. and Swezey, B. 2006. Green Power Marketing in the United States: A Status Report (Ninth Edition), NREL/TP-620-40904. Golden, CO: National Renewable Energy Laboratory, November http://www.eere.energy.gov/greenpower/resources/pdfs/40904.pdf and NREL Factsheet: Status of the U.S. Green Power Market, October 2007.

${ }^{3}$ Energy Star and Other Climate Protection Partnerships 2006 Annual Report, EPA 430-R-07-010, Washington, DC: United States Environmental Protection Agency, September 2007. http://www.epa.gov/appdstar/pdf/AR\%202006\%20Final.pdf

${ }^{4}$ U.S. Energy Information Administration, Electric Power Annual 2005, Revised Data, DOE/EIA-0348(2005), November 2006. http://www.eia.doe.gov/cneaf/electricity/epa/epa_sum.html
} 


\section{Methodology}

\section{Supply-Side Analysis}

The U.S. Energy Information Administration (EIA) collects and reports data on electricity generation from renewable energy sources. ${ }^{5}$ For 2005, the EIA estimates that non-hydro renewable energy sources supplied 94,932 thousand megawatt-hours (MWh) of electricity. ${ }^{6}$ However, for the purposes of this analysis, we are primarily interested in supply from "new" renewable energy generating projects, which are generally defined as projects that came online on or after January 1, 1997.

In order to derive estimates of "new" renewable electricity availability, we used a combination of EIA and EPA data sources. The EIA collects and reports data on U.S. electric generating plants using a number of different data reporting forms. ${ }^{9}$ Using the EIA data, the EPA has designed the Emissions \& Generation Resource Integrated Database (eGRID) to be a comprehensive inventory of environmental attributes of electric power systems. ${ }^{10}$ In reviewing these government databases, we found that eGRID was the most comprehensive and organized data source for our purposes. However, eGRID data is only current through 2004, so it was necessary to supplement eGRID using EIA data collected for 2005, 2006, and 2007 (preliminary).

Table 1 lists the renewable energy fuel types covered in both the EIA and EPA databases. The inclusion of hydropower and municipal solid waste (MSW) raises a number of issues for this analysis because these sources are not often included in "green power" definitions, although they may be acceptable for RPS compliance in some states. Early market definitions distinguished between small hydro ( $\leq 30 \mathrm{MW}$ of nameplate capacity) and large hydro ( $>30 \mathrm{MW})$. More recently, the green power industry has differentiated hydropower plants by their environmental impacts, such as "low-impact" hydropower. ${ }^{11}$ For the purposes of this analysis, we have only included hydropower generation from plants below the $30 \mathrm{MW}$ capacity threshold. As for MSW, the federal data show only 8.5 MW of new capacity additions from 1997 to 2004, thus its inclusion does not significantly affect the overall results.

\footnotetext{
${ }^{5}$ Energy Information Administration, EIA Form 906 and Form 920 collects monthly and annual data on electricity generation and fuel consumption at the power plant and prime mover level for utility and non-utility electric power generators.

${ }^{6}$ For renewables, the EIA distinguishes between "conventional hydropower" and "other renewables." For this analysis, we are most interested in the "other renewables" resource category because (with some exceptions) "conventional hydropower" is generally excluded from certification for voluntary market purchases and from eligibility to meet state renewable portfolio standards.

${ }^{7}$ This is a standard definition of both the Green-e renewable energy certification program (http://www.greene.org/getcert re stan.shtml) and the EPA Green Power Partnership (http://epa.gov/greenpower/buygp/product.htm).

${ }^{8}$ Because of limitations of the source data, the authors are unable to account for cases where an existing plant is repowered or capacity is added to the plant.

${ }^{9}$ Energy Information Administration, EIA Form 860 - Annual Electric Generator Report; EIA Form 906 - Monthly Utility Power Plant Database; EIA Form 920 - Combined Heat and Power Plant Report; EIA Form 767 - Annual Steam-Electric Plant Operation and Design Data.

${ }^{10}$ Environmental Protection Agency, "Emissions \& Generation Resource Integrated Database (eGRID)" URL: http://www.epa.gov/cleanenergy/egrid, accessed September 24, 2007.

${ }^{11}$ Low Impact Hydropower Institute, URL: http://lowimpacthydro.org/, accessed September 24, 2007.
} 
Table 1. Renewable Energy Fuel Types in EIA and EPA Data Bases

- Agricultural crop byproducts

- Black liquor

- Geothermal

- Landfill gas

- Municipal solid waste

- Other biomass solid

- Other biomass liquid
- Other biomass gases

- Solar energy

- Hydroelectric

- Hydroelectric (<30 MW)

- Wood, wood waste solids

- Wood, wood waste liquids

- Wind power

Another issue arises because EIA is not comprehensive in reporting the generation output of the renewable energy plants. To address this issue, we calculated weighted average capacity factors for the plants for which generation was reported. We then applied these capacity factors to the remaining plants to estimate total generation for each renewable energy fuel type. Table 2 presents total "new" U.S. renewable energy capacity and generation for 2004 based on this methodology. Table 3 compares our calculations of "new" capacity and generation with total renewable energy capacity ("existing" and "new") reported by EIA for 2004.

Table 2. "New" Renewable Energy Capacity and Generation in 2004

\begin{tabular}{|l|r|r|}
\hline Primary generator fuel & $\begin{array}{r}\text { Nameplate } \\
\text { capacity } \\
\text { (MW) }\end{array}$ & $\begin{array}{r}\text { Estimated } \\
\text { net } \\
\text { generation } \\
\text { (MWh) }^{\mathbf{1 2}}\end{array}$ \\
\hline Agricultural crop byproducts & 52.7 & 145,260 \\
\hline Black liquor & 198.8 & 839,725 \\
\hline Geothermal & 67.8 & 567,914 \\
\hline Landfill gas & 383.4 & $2,279,830$ \\
\hline Municipal solid waste & 8.5 & 22,005 \\
\hline Other biomass solid & 24.5 & 69,760 \\
\hline Other biomass liquid & ---- & ------- \\
\hline Other biomass gases & 28.2 & 41,033 \\
\hline Solar energy & 7.6 & 14,093 \\
\hline Small hydroelectric $(\leq 30 M W)$ & 294.1 & $1,041,322$ \\
\hline Wood, wood waste solids & 148.9 & 794,811 \\
\hline Wind power & $\underline{4,514.9}$ & $11,117,236$ \\
\hline & $\mathbf{5 , 6 7 7 . 0}$ & $\mathbf{1 6 , 7 8 7 , 7 2 9}$ \\
\hline
\end{tabular}

\footnotetext{
${ }^{12}$ Generation estimated using the following weighted average capacity factors: Agricultural crop byproducts: 0.31 ; Black liquor: 0.48; Geothermal: 0.96; Landfill gas: 0.68; Municipal solid waste: 0.3; Other biomass solid: 0.33; Other biomass gases: 0.17; Solar energy: 0.21; Hydroelectric: 0.26: Small hydroelectric ( $\leq 30 \mathrm{MW})$ : 0.4; Wood, wood waste solids: 0.61 ; Wind power: 0.28 . These capacity factors were estimated by the authors using available capacity and generation data from EIA forms 860 and 906/920.
} 
Table 3. Comparison of Estimated "New" Renewable Energy Capacity and Generation with U.S. Totals in 2004

\begin{tabular}{|c|c|c|}
\hline Primary generator fuel & $\begin{array}{r}\text { "New" } \\
\text { nameplate } \\
\text { capacity } \\
(\mathrm{MW}) \\
\end{array}$ & 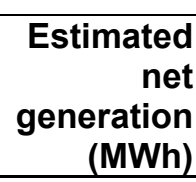 \\
\hline Biomass & 845.0 & $4,192,424$ \\
\hline Geothermal & 67.8 & 567,914 \\
\hline Solar energy & 7.6 & 14,093 \\
\hline Small hydroelectric $(\leq 30 \mathrm{MW})$ & 294.1 & $1,041,322$ \\
\hline Wind power & $\underline{4,514.9}$ & $\underline{11,117,236}$ \\
\hline Total & $5,677.0$ & $16,787,729$ \\
\hline Primary generator fuel & $\begin{array}{r}\text { Total } \\
\text { nameplate } \\
\text { capacity } \\
(\mathrm{MW}) \\
\end{array}$ & $\begin{array}{r}\text { Total } \\
\text { generation } \\
(\mathrm{MWh}) \\
\end{array}$ \\
\hline Biomass & 9,757 & $60,878,599$ \\
\hline Geothermal & 2,152 & $14,810,974$ \\
\hline Solar energy & 398 & 575,155 \\
\hline Small hydroelectric $(\leq 30 \mathrm{MW})^{*}$ & ---- & --------- \\
\hline Wind power & $\underline{6,456}$ & $\underline{14,143,741}$ \\
\hline Total non-hydro & 18,763 & $90,408,469$ \\
\hline
\end{tabular}

*Not distinguished from "large" hydro in EIA statistics

Source: U.S. Energy Information Administration, Renewable Energy Annual 2005, July 2007.

The next step in our calculations was to add estimated capacity additions and generation for 2005, 2006, and 2007. We did this by using EIA-collected data on both actual and projected renewable energy capacity additions for these years, ${ }^{13}$ and again applying weighted average capacity factors to estimate the total generation for each renewable energy fuel type. ${ }^{14}$ Table 4 displays the resulting estimated capacity and generation figures for 2007.

\footnotetext{
${ }^{13}$ Energy Information Administration, EIA Form 860 data as reported in "Electric Generating Unit Additions, 2005", "Electric Generating Unit Additions, 2006", and "Proposed U. S. Electric Generating Units by Year, Month, Company and Plant, January 2007 - December 2007”, URL:

http://www.eia.doe.gov/cneaf/electricity/page/capacity/capacity.html, accessed September 24, 2007.

${ }^{14}$ For wind power, we used a .32 capacity factor for estimates of installed capacity after 2005 , based on information from Black \& Veatch “AWEA Roadmap Project: Initial Thoughts," presentation by Ryan Pletka, Ryan Jacobson, Ric O’Connell, June 2006.
} 
Table 4. Estimated “New” Renewable Energy Capacity and Generation for 2007

\begin{tabular}{|l|r|r|}
\hline Primary generator fuel & $\begin{array}{r}\text { Estimated } \\
\text { "New" } \\
\text { Capacity } \\
\text { (MW) }\end{array}$ & $\begin{array}{r}\text { Estimated } \\
\text { "New" } \\
\text { Generation } \\
\text { (MWh) }\end{array}$ \\
\hline Agricultural crop byproducts & 182.4 & 502,870 \\
\hline Black liquor & 206.2 & 871,151 \\
\hline Geothermal & 175.0 & $1,466,775$ \\
\hline Landfill gas & 485.0 & $2,884,644$ \\
\hline Municipal solid waste & 51.2 & 132,547 \\
\hline Other biomass solid & 24.5 & 69,760 \\
\hline Other biomass liquid & 2.0 & 0 \\
\hline Other biomass gases & 28.2 & 41,033 \\
\hline Solar energy & 80.1 & 149,466 \\
\hline Small hydroelectric $(\leq 30 \mathrm{MW})$ & 332.0 & $1,175,843$ \\
\hline Wood, wood waste solids & 174.9 & 933,810 \\
\hline Wind power & $\underline{12,178.9}$ & $\underline{30,006,736}$ \\
\hline & $\mathbf{1 3 , 8 6 7 . 9}$ & $\mathbf{3 8 , 0 8 8 , 4 8 6}$ \\
\hline
\end{tabular}

Our final task for the supply-side analysis is to project potential renewable electricity supply to 2010. It is evident from Table 4 that wind energy represents a majority of the "new" renewable electricity supply. While increased deployment activity is occurring across all renewable electric technologies, over the next three years we expect that wind energy will continue to dominate new renewables capacity additions. Thus, for first-order projection purposes, we focus on the design of two different scenarios for wind capacity additions while assuming again for simplicity that deployment of the other renewable energy technologies occurs at their respective recent historical rates. That is, for each technology a separate growth rate is used. In this respect, our projections most likely underestimate the contribution from other renewable energy sources. ${ }^{15}$

Our projections present two scenarios for wind energy additions from 2008 to 2010: 1) a base case, which assumes constant additions of 4,000 MW of wind energy per year through 2010 based on a revised preliminary wind industry estimate of additions in $2007^{16}$ —and 2) a high case, which assumes 5,000 MW of new capacity in 2007 and 2008, 6,000 MW in 2009, and 7,000 MW in 2010. Table 5 presents the resulting renewable electricity supply for these two scenarios.

\footnotetext{
${ }^{15}$ This analysis does not account for incremental capacity additions — such as re-powering - to plants built on or after January 1, 1997, which may in some cases be considered "new" generating capacity.

${ }^{16}$ Assumption based on recent discussions with the American Wind Energy Association. AWEA earlier estimated 3,000 MW of new capacity in 2007, but is revising that estimate upwards. See American Wind Energy Association, "AWEA Quarterly Market Report: U.S. Wind Power Industry Looks At Record Year, Supply Chain Constraints" August 8, 2007. http://www.awea.org/newsroom/releases/AWEA_Quarterly_Market_Report 080807.html
} 
Table 5. NREL Projection of U.S. “New” Renewable Electricity Supply from 2008 to 2010 (MWh)

\begin{tabular}{|l|c|c|c|}
\hline & $\mathbf{2 0 0 8}$ & $\mathbf{2 0 0 9}$ & $\mathbf{2 0 1 0}$ \\
\hline Base Case & $55,650,912$ & $68,963,614$ & $83,413,390$ \\
\hline High Case & $61,257,312$ & $80,176,414$ & $103,035,790$ \\
\hline
\end{tabular}

\section{Demand-Side Analysis}

For estimating current demand, we are most interested in demand from voluntary purchase markets and state RPS policies. Although several utilities have invested in new renewable energy generation to serve their ratepayers with least-cost resources, as new RPS policies proliferate, we assume that over the time period of interest (2010) all eligible renewable energy generation will be used to supply either voluntary or compliance markets.

\section{Voluntary Markets}

NREL reports data on national demand from voluntary markets by market segment. Growth in U.S. voluntary market demand averaged $46 \%$ per year from 2003 to 2006. (Table 6)

Table 6. NREL Estimates of U.S. Green Power Sales (thousands of MWh)

\begin{tabular}{|l|c|c|c|c|}
\hline & $\mathbf{2 0 0 3}$ & $\mathbf{2 0 0 4}$ & $\mathbf{2 0 0 5}$ & $\mathbf{2 0 0 6}$ \\
\hline Utility Green Pricing & 1,280 & 1,840 & 2,450 & 3,400 \\
\hline Competitive Markets & 1,900 & 2,650 & 2,150 & 1,700 \\
\hline REC Markets & 660 & 1,720 & 3,890 & 6,800 \\
\hline Retail Total & $\mathbf{3 , 8 4 0}$ & $\mathbf{6 , 2 1 0}$ & $\mathbf{8 , 4 9 0}$ & $\mathbf{1 1 , 9 0 0}$ \\
\hline Annual Growth Rate & ----- & $62 \%$ & $37 \%$ & $41 \%$ \\
\hline
\end{tabular}

Sources: Bird, L. and B. Swezey, 2006. Green Power Marketing in the United States: A Status Report (Ninth Edition), NREL/TP-62040904. Golden, CO: National Renewable Energy Laboratory, November

(http://www.eere.energy.gov/greenpower/resources/pdfs/40904.pdf ) and NREL Factsheet: Status of the U.S. Green Power Market, October 2007.

We assume that voluntary market demand will grow at an average annual rate of $35 \%$ from 2007 through 2010. Under this assumption, voluntary market demand will grow to nearly 40 million MWh in 2010 (see Table 7). 
Table 7. Estimates of U.S. Green Power Sales Extrapolated at 35\% AAGR (thousands of MWh)

\begin{tabular}{|l|c|c|c|c|}
\hline & $\mathbf{2 0 0 7}$ & $\mathbf{2 0 0 8}$ & $\mathbf{2 0 0 9}$ & $\mathbf{2 0 1 0}$ \\
\hline Retail Total & 16,065 & 21,688 & 29,278 & 39,526 \\
\hline
\end{tabular}

\section{Compliance (RPS) Markets}

The Union of Concerned Scientists (UCS) documents individual state RPS policies and estimates the amount of renewable electricity necessary to fully comply with each state policy. ${ }^{17} \mathrm{UCS}$ calculates the total renewable electricity requirements categorized as "existing" and "new" renewable electricity supplies. Again, for this analysis we are only interested in the demand for "new" renewable energy sources. Table 8 shows the UCS RPS demand calculations for 2003 through 2010.

Table 8. UCS Estimates of Aggregate State RPS Compliance Requirements for New Renewable Energy, 2003 to 2010 (thousands of MWh)

\begin{tabular}{|l|c|c|c|c|c|c|c|c|}
\hline & 2003 & 2004 & 2005 & 2006 & 2007 & 2008 & 2009 & 2010 \\
\hline $\begin{array}{l}\text { Aggregate } \\
\text { Total }\end{array}$ & 3,776 & $\mathbf{9 , 0 6 0}$ & $\mathbf{1 3 , 7 4 0}$ & $\mathbf{2 0 , 8 4 6}$ & $\mathbf{3 1 , 3 8 8}$ & $\mathbf{4 4 , 2 8 1}$ & $\mathbf{5 7 , 6 4 4}$ & $\mathbf{7 1 , 9 0 1}$ \\
\hline $\begin{array}{l}\text { Annual } \\
\text { Growth } \\
\text { Rate }\end{array}$ & -- & $140 \%$ & $52 \%$ & $52 \%$ & $51 \%$ & $38 \%$ & $28 \%$ & $25 \%$ \\
\hline
\end{tabular}

Source: Union of Concerned Scientists

\section{The Supply and Demand Balance}

Figure 1 compares our demand estimate for "new" renewable electricity from voluntary and compliance (RPS) markets with our two renewable electricity supply scenarios for the period 2004 through 2010. Voluntary market demand is currently, and is expected to remain, below both existing and projected renewable electricity supply. However, when combined with RPS requirements, total demand from these two markets already today slightly exceeds the available supply of "new" renewable electricity and the gap becomes more pronounced through 2010 as state RPS requirements ramp up. However, under the more optimistic growth path for new wind energy capacity additions, the gap narrows considerably. In 2010, the projected shortfall is 28 million MWh under the base case scenario and 8 million MWh under the high wind scenario.

\footnotetext{
${ }^{17}$ Union of Concerned Scientists, "State Clean Energy Policies," URL: http://www.ucsusa.org/clean_energy/clean_energy_policies/clean-energy-policies-and-proposals.html, accessed September 24, 2007.
} 


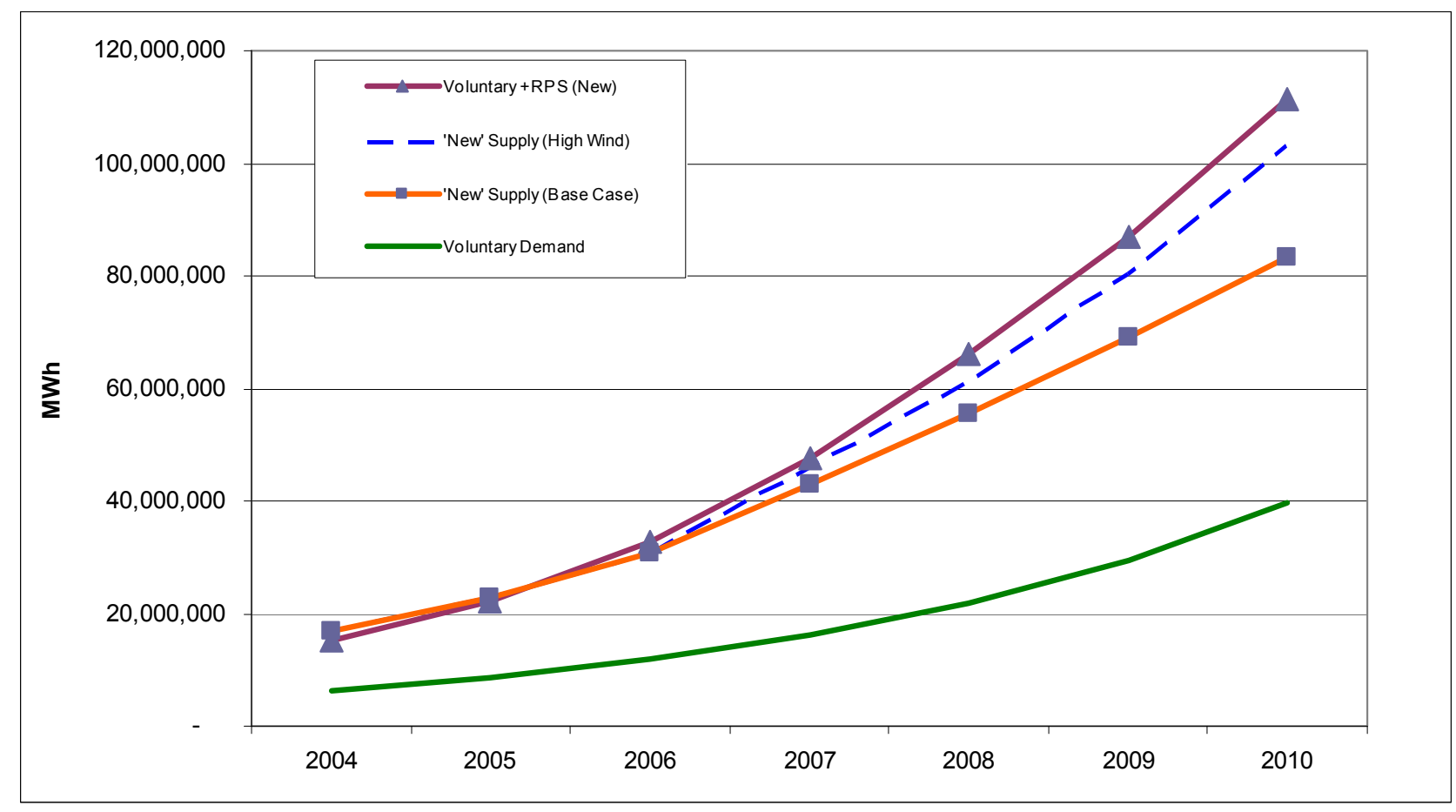

Figure 1. Estimated and Projected Supply and Demand for Renewable Electricity

\section{Implications}

The implications of our analysis are clear: nationally, there is a need to accelerate renewable energy deployment from all sources to meet the burgeoning demand from both compliance and voluntary markets. While this analysis suggests a near-term deficit in renewable electricity supplies, our results do not necessarily portend a long-term shortage as it is likely that, with continuing federal and state support, the renewable energy industry can greatly ramp up deployment and production over the medium and long term.

Finally, below we describe a number of factors that could possibly alter the magnitude of the near-term renewable electricity shortage that we have identified.

\section{Growth in Voluntary Markets}

Recent growth in voluntary market purchases has depended on an adequate supply of renewable electricity at a reasonable price. If renewable electricity shortages develop, it is likely that renewable electricity prices will rise. Higher prices would dampen voluntary demand and RPS demand might even outbid some existing voluntary demand as state non-compliance penalties and alternative compliance payment levels set the market price. Under such a scenario, voluntary market demand would go unmet. Other factors that could affect growth in voluntary markets are competition from energy efficiency certificates and demand for carbon offsets. In addition, demand for voluntary market RECs could decline if carbon regulations are adopted that prevent 
green power purchases from affecting GHG emission levels and thus limit claims that can be made by marketers and purchasers. ${ }^{18}$

\section{RPS Compliance}

It is possible that some states will not achieve full compliance with their RPS requirements, thus reducing overall renewable electricity demand. This situation could be exacerbated by state restrictions on renewable resource eligibility. ${ }^{19}$ On the other hand, as state RPS compliance levels ramp up, excess supplies of renewable energy credits in RPS states, which are currently available for voluntary purchases, could disappear.

\section{Banking or Holding RECs}

If a significant number of electric utilities and other electricity suppliers choose to bank RECs for future RPS compliance, excess supplies may not be available for voluntary markets. Furthermore, if generators choose to hold RECs in anticipation of future regulation, this would also reduce total supply.

\section{Regional Factors}

Regional differences may result in greater availability of supply for the voluntary market than suggested by the aggregate national picture. For example, some states, such as Texas, may have renewable energy generation in excess of that needed to meet RPS requirements, while others may experience shortages. Any excess generation that is not eligible to be used for RPS compliance would be available to meet voluntary market demand. Such state or region-specific analyses are outside the scope of this paper, but should be conducted in the future.

\section{Passage of Additional State RPS Policies and/or a Federal RPS}

Currently, 25 states and the District of Columbia have RPS policies. If additional states pass RPS laws or expand existing renewable energy targets, or if a federal RPS is enacted, the undersupply situation would be exacerbated. However, additional policies would not be expected to have a measurable impact until after 2010.

\section{Pending Expiration of Federal Renewable Energy Tax Credits}

Currently, renewable energy development relies on a number of federal tax incentives which are scheduled to expire at the end of 2008. If these federal incentives are not extended, particularly the production tax credit (PTC), it is unlikely that we will achieve the level of supply additions assumed here. In fact, the longer the extension decision is delayed, the greater the uncertainty

\footnotetext{
${ }^{18}$ See, for example, Bird, L., E. Holt, and G. Carroll, 2007. Implications of Carbon Regulation for Green Power Markets, NREL/TP-640-41076. Golden, CO: National Renewable Energy Laboratory, April. http://www.eere.energy.gov/greenpower/resources/pdfs/41076.pdf

${ }^{19}$ See, for example, Cory, K. and B. Swezey. "Renewable Portfolio Standards in the States: Balancing Goals and Rules," The Electricity Journal, 20 (4), p.21-32, May 2007.
} 
(and risk) that renewable energy developers face in moving ahead with new projects. This situation, in and of itself, is likely to cause some delay in new capacity additions.

\section{Supply Contribution from Wind and Non-Wind Renewables}

Our supply-side renewables analysis focuses on the prospects for new wind energy development. There is significant uncertainty in the amount of wind energy capacity that will be added in the coming years. If wind energy capacity additions substantially exceed our base case estimates, this does cause a significant upward movement of the renewable electricity supply curve. In addition, our analysis assumes that supply additions from other renewable energy sources will only increase at recent average rates. However, a number of new projects have been announced that could result in a greater future contribution from these sources. For example, California utilities have contracted for more than 1,000 MW of new solar energy generation capacity to be operational in 2010, and development activity in new geothermal and biomass projects is also gathering momentum. Nevertheless, by 2010, the supply impact of these potential resource additions is not likely to change our overall findings significantly. 


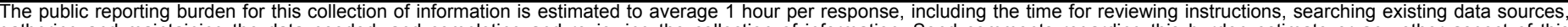

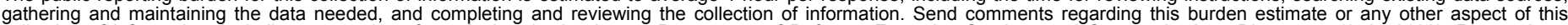

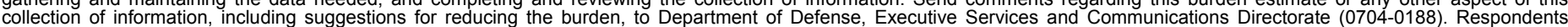

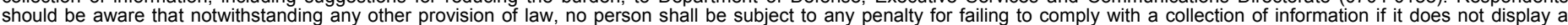

currently valid OMB control number.

PLEASE DO NOT RETURN YOUR FORM TO THE ABOVE ORGANIZATION.

\begin{tabular}{l|l|l|l} 
1. REPORT DATE $(D D-M M-Y Y Y Y)$ & 2. & REPORT TYPE & 3. DATES COVERED (FrOm - TO)
\end{tabular} October 2007

Technical Report

4. TITLE AND SUBTITLE

A Preliminary Examination of the Supply and Demand Balance

for Renewable Electricity

5a. CONTRACT NUMBER

DE-AC36-99-G010337

5b. GRANT NUMBER

5c. PROGRAM ELEMENT NUMBER

6. AUTHOR(S)

Blair Swezey, Jørn Aabakken, and Lori Bird

5d. PROJECT NUMBER

NREL/TP-670-42266

5e. TASK NUMBER

WF6N.1015

5f. WORK UNIT NUMBER
7. PERFORMING ORGANIZATION NAME(S) AND ADDRESS(ES)

9. SPONSORING/MONITORING AGENCY NAME(S) AND ADDRESS(ES)

National Renewable Energy Laboratory

1617 Cole Blvd.

Golden, CO 80401-3393 8. PERFORMING ORGANIZATION
REPORT NUMBER
10. SPONSOR/MONITOR'S ACRONYM(S) NREL

11. SPONSORING/MONITORING AGENCY REPORT NUMBER NREL/TP-670-42266

12. DISTRIBUTION AVAILABILITY STATEMENT

National Technical Information Service

U.S. Department of Commerce

5285 Port Royal Road

Springfield, VA 22161

13. SUPPLEMENTARY NOTES

NREL Technical Monitor:

14. ABSTRACT (Maximum 200 Words)

In recent years, the demand for renewable electricity has accelerated as a consequence of state and federal policies and the growth of voluntary green power purchase markets, along with the generally improving economics of renewable energy development. This paper reports on a preliminary examination of the supply and demand balance for renewable electricity in the United States, with a focus on renewable energy projects that meet the generally accepted definition of "new" for voluntary market purposes, i.e., projects installed on or after January 1, 1997. After estimating current supply and demand, this paper presents projections of the supply and demand balance out to 2010 and describe a number of key market uncertainties.

\section{SUBJECT TERMS}

NREL; EPA's Green Power Partnership; U.S. Energy Information Administration; green power; Renewable Energy Fuel Types; Renewable Energy Capacity; Voluntary Markets; Compliance Markets; RECs; Blair Swezey; Jørn Aabakken; Lori Bird

\begin{tabular}{|c|c|c|c|c|}
\hline 16. SECURIT & CLASSIFICATI & N OF: & 17. LIMITATION & 18. NUMBER \\
\hline $\begin{array}{l}\text { a. REPORT } \\
\text { Unclassified }\end{array}$ & $\begin{array}{l}\text { b. ABSTRACT } \\
\text { Unclassified }\end{array}$ & $\begin{array}{l}\text { c. THIS PAGE } \\
\text { Unclassified }\end{array}$ & UL & \\
\hline
\end{tabular}

\begin{tabular}{l} 
19a. NAME OF RESPONSIBLE PERSON \\
19b. TELEPHONE NUMBER (Include area code) \\
\hline
\end{tabular}

